\title{
A New Two-Pillar Strategy for the ECB
}

\author{
Paul De Grauwe \\ Daniel Gros
}

\author{
CESIFO WORKING PAPER NO. 2818 \\ CATEgORY 7: MONETARY Policy and InTERnational Finance \\ OCTOBER 2009
}

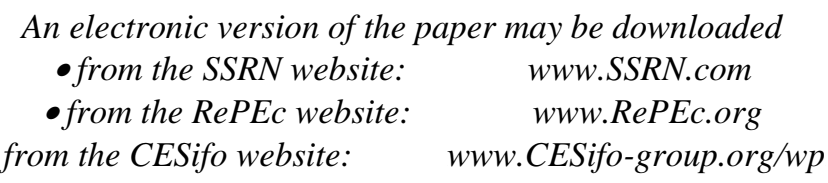




\title{
A New Two-Pillar Strategy for the ECB
}

\begin{abstract}
The ECB has been arguing in the past that since there is no trade-off between price stability and financial stability, the pursuit of price stability is the best a central bank can do to also maintain financial stability. We argue that there is a potential trade-off between price stability and financial stability. In order to make this trade-off less constraining we propose that the two-pillar strategy of the ECB should be reformed. In this new two-pillar strategy, the ECB should pursue two objectives, i.e. price stability and financial stability. In this new strategy the interest rate should be used to achieve the inflation objective, while other instruments (minimum reserve requirements and macro prudential control) should be used to achieve financial stability.
\end{abstract}

JEL Code: E52, E53.

Keywords: inflation targeting, financial stability, two pillar strategy.

Paul De Grauwe

University of Leuven

Faculty of Economics

Room 02.150 - Naamsestraat 69

Belgium - 3000 Leuven

Paul.degrauwe@econ.kuleuven.be
Daniel Gros

CEPS

Centre for European Policy Studies

1 Place du Congres

Belgium - 1000 Brussels

danielg@ceps.eu

June 2009

We are grateful to Claudia Cicconi for very expert research assistance. 


\section{Introduction}

The financial crisis of 2007-08 has called into question the mainstream view that price stability should be not merely the primary, but effectively the only objective of a central bank. After all the major central banks, including the ECB, were quite successful in maintaining price stability during the last decade. Yet this remarkable success in keeping inflation low has not prevented a financial crisis from erupting. This leads to the question of whether financial stability is not equally important as an objective of the central bank?

Before the emergence of the crisis the standard response to that question was, first, that by maintaining price stability the central bank did all what it could do to maintain financial stability. In other words, price stability was seen as a strategy that would minimize the risk of financial instability. Second, the main responsibility for maintaining financial stability is in the hands of the supervisors and regulators.

There can be no doubt that the responsibility of the supervisors and the regulators is a formidable one. But does this absolve the central bank from its responsibilities? To answer this question we have to formulate another one. Is it conceivable that there is a tradeoff between price stability and financial stability (much in the same way as there can be a tradeoff between price stability and output stability when supply shocks occur)? If there is none, the central bank can indeed claim that by maintaining price stability it does all what it can to also maintain financial stability. If there is a tradeoff between price stability and financial stability, the central bank will have to make a choice. In that case the issue arises which of the two objectives should have precedence: price stability or financial stability. We analyse how such a trade off can arise in Section 2. Section 3 then turns to the issue how to define and monitor financial stability. Section 4 then looks at the policy instruments the ECB could deploy to maintain financial stability. Section 5 concludes.

\section{Is there a trade-off between price stability and financial stability?}

Much of central banking has to do with resolving trade-offs. The one that has occupied most of the attention both of practitioners and theoreticians is the trade-off between inflation and unemployment (output growth). There is now general agreement that while in the short run a powerful trade-off exists; in the long run it vanishes. This is why central banks were given one target, price stability, and one instrument, namely the interest rate, to achieve it.

Does there exist a similar trade-off between inflation and financial stability? At first sight, there does not seem to be a similar trade-off as the one between price stability and unemployment. Thus, the choice faced by the central bank does not seem to be comparable to the choice between inflation and unemployment.

Nevertheless, trade-offs between inflation and financial stability may appear in a different form. Financial stability is a complex concept and more difficult to define than price 
stability, which can be summarized in a single number, namely CPI inflation. In what follows financial stability is intended as absence of financial instability, i.e. a situation of distress which does not allow the financial and, in particular, the banking system to function normally.

In order to analyze these different trade-offs it is useful to trace how bubbles work through demand and supply, and in so doing, create trade-offs between inflation and financial stability.

Let's take the case of the IT-driven asset bubble of the late 1990s as our prototype bubble (see Kindleberger (2000) for an analysis of similar technology-driven bubbles in history). A new technology leads to great optimism about the future potential of that technology. This leads to large increases in stock prices. These reduce the cost of attracting capital which in turn increases investment in these new technologies. The primary effect of such a shock is to increase productivity so that the aggregate supply curve shifts to the right.

The same shock, however, also increases aggregate demand. New technologies create new products and thus lead consumers to spend more. We will assume here that the supply effect is larger than the demand effect. We show this case in Figure 1. The new technology shifts demand and supply to the right (from AD to AD' and AS to AS'). However the supply effect is stronger than the demand effect. As a result, in the new equilibrium given by point $B$, the aggregate price level has declined to P'. Much of the subsequent dynamics now depends on the policy regime. Suppose the central bank targets the price level at the level $\mathrm{P}^{*}{ }^{1}$. We then immediately see that the central bank will respond by a policy of monetary stimulus (lower interest rate, higher money stock) so as to raise demand and the price level from $\mathrm{P}^{\prime}$ to $\mathrm{P}^{*}$. We show this by a shift of the demand curve from AD' to AD',. The economy settles in point $\mathrm{C}$.

The result of this monetary accommodation is to keep the price level at its pretechnological shock, $\mathrm{P}^{*}$. Thus the central bank maintains price stability. The monetary stimulus, however, also increases the level of the asset prices even further relative to the position that was attained when the price level was P'. This creates a risk that the asset price increase degenerates into a bubble. Since bubbles inevitably lead to crashes and since financial institutions are usually involved in asset price inflation financial stability is endangered.

\footnotetext{
${ }^{1}$ Note that in practice the central bank targets inflation, but the argument could be phrased in terms of inflation.
} 
Figure 1: The trade-off between price stability and financial stability due to a technologydriven shock

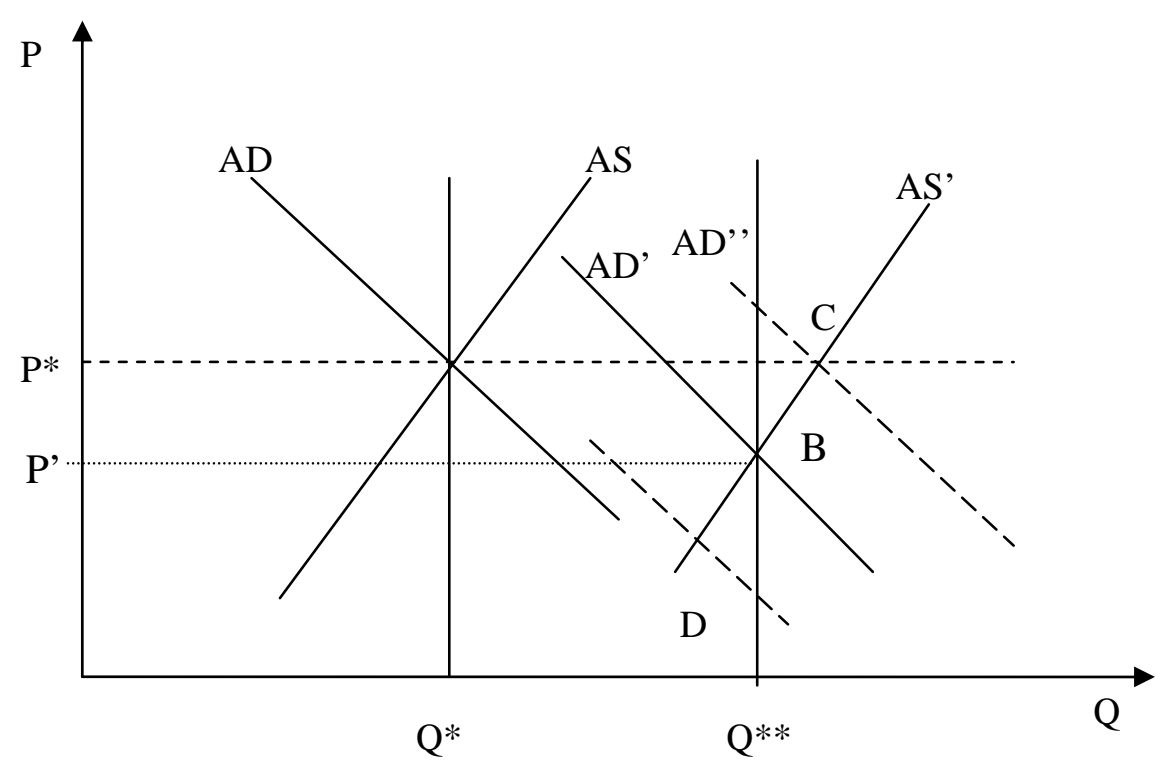

Thus there seems to be a trade-off here between price stability and financial stability in the presence of a technology shock. The trade-off arises because the technology shock has the effect of reducing the aggregate price level. The central bank, however, targets a price level corresponding to the pre-technology shock level. As a result, it is forced to react to the shock by a monetary stimulus, creating an environment that makes a bubble more likely, while keeping the price level unchanged ${ }^{2}$.

This analysis comes close to what Kindleberger has identified to be the main sources of the development of a bubble. These are first a technological revolution, and second a monetary accommodation. The two together provide for the cocktail that in history most often leads to bubbles and later crashes ${ }^{3}$.

The equilibrium reached in point $\mathrm{C}$ is unsustainable (the long run equilibrium is in point B) and therefore can only be temporary. Output is beyond full capacity. It is sustained at that level by an interest rate that is too low and by the high level of asset prices that create a positive wealth effect on aggregate demand. Because point $C$ is unsustainable a crash is inevitable. The crash leads to a decline in aggregate demand. It is likely to lead to an overreaction, as consumers and producers who have indebted themselves have to improve their balance sheets again. Thus the demand curve shifts to the left. A new (temporary) equilibrium is reached in point $\mathrm{D}$. The economy is in a recession, with output located below full capacity. It should be noted that once in point $\mathrm{D}$, the trade-off for the central

\footnotetext{
${ }^{2}$ Borio (2003) argues that while low and stable inflation promotes financial stability, it also increases the likelihood that excess demand pressures show up first in credit aggregates and asset prices, rather than in goods and services prices.

${ }^{3}$ It is also the dynamics underlying the IT bubble during the second half of the 1990s. The US monetary authorities identified this shock as a productivity shock that tended to lower prices and thus made a monetary expansion desirable. See Greenspan (2007).
} 
bank disappears. The latter, by targeting the price level, will stimulate aggregate demand thereby allowing the price level and the output level to increase. Whether this monetary stimulus is effective is another matter (not analyzed here). Experience has shown that during major busts monetary stimulus may become ineffective (as a result of a liquidity trap, as in Japan over the last decades).

The analysis underlying Figure 1 stresses the importance of technological shocks. The latter were important for explaining the IT bubble of the late 1990s that crashed in 2001. Not all bubbles are technology-driven, however. The stock market bubble that started in 2003 and crashed in 2007/2008 does not appear to have been driven by a technology shock. It is not fully clear how this bubble was triggered. It appears though that it was mainly caused by a combination of "animal spirits", i.e. optimistic beliefs of investors, and excessive credit creation.

We analyze this case in Figure 2 because we believe this is the type of bubble most relevant to understand the macroeconomic disequilibria in the euro zone during 2003-07. We start from the initial equilibrium in point $\mathrm{C}$. A bubble is now set in motion as a result of "animal spirits". This raises stock prices and lowers the cost of capital. The supply curve shifts down from AS to AS'. At the same time the bubble in asset markets raises aggregate demand due to wealth effects and to the increased availability of credit. The latter arises because the banks' balance sheets move upward with the bubble. The mechanism is that the higher price of assets increases the collateral value of these assets and thus the potential for bank credit. "Mark-to-market" rules reinforce this effect (both during the upturn as later during bust). Moreover, in the benign economic environment (high growth, but stable prices) generated by a positive supply shock, as risk apparently has fallen, leverage increases. All this implies that for any given supply of capital to the banking system the availability of credit ${ }^{4}$ increases which increases the opportunities for marginal (sub prime) consumers to finance additional consumption (or the purchase of durable consumer goods like cars or houses).

This increase in the availability of credit, also often dubbed 'liquidity' implies thus that aggregate demand curve shifts to the right, e.g. from $\mathrm{AD}$ to $\mathrm{AD}$ '. We assume that these two effects are of the same magnitude. It does not have to be, but we use this assumption because it presents a useful benchmark. Moreover, it appears to characterise the case of the euro area well since the external current account of the euro area has remained in rough equilibrium over the last ten years, suggesting that supply and demand have moved in parallel ${ }^{5}$. The important general point is that both demand and supply shift. As a result, the central bank which is targeting $\mathrm{P}$ at the level $\mathrm{P}^{*}$ decides that there is nothing to worry about.

There is, however, a lot to worry about. The expansion of output is unsustainable because it is based on credit creation which is linked to artificially high asset valuations. In addition, in this process of excessive credit creation, households and firms accumulate

\footnotetext{
${ }^{4}$ See the 'The Fundamental Principles of Financial Regulation', 2009

${ }^{5}$ The case of the US is obviously different. Its increasing current account deficit (until 2006 at least) shows that demand growth was higher than supply growth. For the US one would have to add to the model imports, which would render the supply curve (at leas of tradables) much flatter.
} 
excessive debt which will have to be scaled down. This happens when the bubble bursts. At that moment both demand and supply shift to the left. They will typically undershoot creating a recession. All this will lead to banking problems and a financial crisis as all the mechanisms which reinforced the availability of credit during the boom go into reverse.

Figure 2 The trade-off between price stability and financial stability due to "animal spirits"

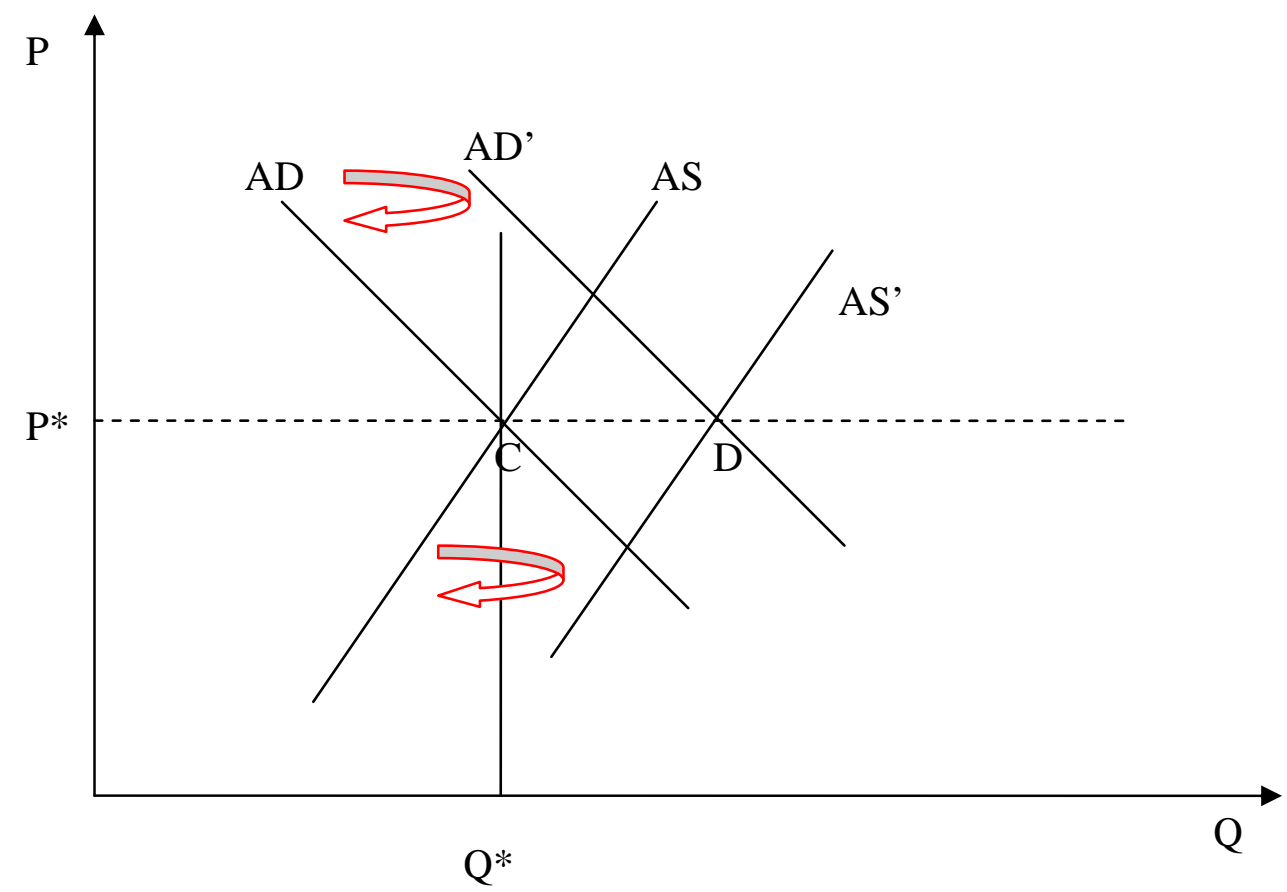

From the preceding analysis we conclude that important trade-offs between price stability and financial stability arise when technological developments trigger booms in asset markets or when "animal spirit" create a cycle of booms and busts. A central bank that uses a lexicographic ordering favouring price stability over other objectives is likely to fuel the boom inadvertently (in the case of a technology-driven bubble) or will decide to do nothing (in the case of an "animal spirit bubble") allowing a process of excessive credit creation. The latter is what happened during the last ten years. Major central banks (including the ECB) focused exclusively on price stability, and were quite successful in keeping inflation low. (The Federal Reserve did focus on financial stability only when financial markets (especially stock markets) fell and it had the feeling that a lack of availability of credit might hamper a recovery.) ${ }^{6}$ They failed, however, to see the bubbles in asset markets that were threatening financial stability, and that they fuelled inadvertently by allowing excessive credit creation to develop. In doing this they failed to achieve their ultimate objectives. These are situations in which central banks should have put their inflation target aside so as to guarantee financial stability.

\footnotetext{
${ }^{6}$ This approach is known in the literature as the 'benign neglect". According to this view monetary authorities should deal with financial instability that may result from an asset bubble crash if and when the latter occurs. See Bordo and Jeanne (2002).
} 
We also conclude that the lexicographic ordering of the objectives of the ECB should be abandoned. Strict inflation targeting cannot be maintained because it can conflict with financial stability. Our contention is that when such a conflict arises, the central bank should allow its inflation target to be overridden by the objective of financial stability (see Borio and Lowe (2002) and White(2006) for a similar conclusion) ${ }^{7}$. We do not suggest that the trade off between price and financial stability is always present, but it is clear that this trade off has been present over the last decade and has been neglected at great cost.

Promoting financial stability to a level at par with price stability creates a number of issues, however. We discuss two issues here. The first one has to do with the definition and the monitoring of financial stability; the second one with the instruments a central bank, including the ECB, can use to reach the objective of financial stability. We will not deal with possible legal issues that arise from the fact that the statutes of the ECB may have to be changed.

\section{How to define and to monitor financial stability?}

While the definition of price stability and thus its monitoring is relatively easy, this cannot be said of the objective of financial stability ${ }^{8}$. Defining financial stability is more difficult than defining price stability because the former has different dimensions that do not lend themselves to be captured by one index in the way this is done to describe price stability. As a result, the monitoring of financial stability is also inherently more difficult than the monitoring of price stability (through the use of the Consumer Price Index).

The literature offers few formal definitions of financial stability. For example, Ferguson (2002) defines financial stability through its contrary: financial instability. Financial instability is a situation in which: "a) some important set of financial asset prices seem to have diverged sharply from fundamentals; and/or b) market functioning and credit availability, domestically and perhaps internationally, have been significantly distorted; with the result that c) aggregate spending deviates (or is likely to deviate) significantly from the economy's ability to produce."

Borio and Lowe (2002) use a similar definition of financial instability. According to these authors, sustained rapid credit growth combined with large increases in asset prices increases the probability of an episode of financial instability (see also Borio (2003)). This view of the simultaneous occurrence of bubble-like developments in asset markets

\footnotetext{
${ }^{7}$ This is certainly not the mainstream view. The latter is represented by Svensson (2002) who argues that the central bank should focus on its objective of price stability with financial stability concerns only entering in an extreme scenario when a crisis is underway. This was also the Greenspan (2007) view and was very much influenced by Bernanke and Gertler (2000).

${ }^{8}$ We are not implying that the definition of price stability does not create problems. See De Grauwe (2007) for a discussion.
} 
and excessive credit growth as twin indicators of threats to financial stability is also to be found in Kindleberger (2000) and formed the basis of our theoretical analysis ${ }^{9}$.

In a recent paper, Alessi and Detken (2008), argue that credit growth at the global level is a better predictor for the emergence of financial crisis than national credit growth. This means that the ECB should not be looking only at euro area variables when it wants to evaluate potential dangers to financial stability. Recent experience has shown that excessive mortgage lending in the US can lead to financial distress in Europe. An institution concerned with financial stability in the euro area should have taken this into account when setting its own policy. Moreover, given that euro area variables constitute an important share of global averages this result still implies that euro area variables contain an important signal about potential risks for financial stability.

Thus by focusing on two types of variables, i.e. asset prices and credit growth, the monetary authorities can obtain important information about ongoing developments that can threaten financial stability.

We show as an example the evidence of the most recent episode.

In Figure 3 we present the stock prices in the euro area and the US. We observe in both cases a bubble-like development from about 2003 onwards up to the middle of 2007, followed by a steep crash (for the US). Note that the bubble appears to have been as pronounced in the euro area as in the US.

The bubble in stock prices appears to have coincided with a strong acceleration of bank credit from 2003 on. We show the evidence for the euro area in Figure 4. We observe that the yearly growth rates of total bank loans in the euro area increased from less than $4 \%$ per year in 2003 to double-digit growth rates during 2006-07 (which was the period during which stock prices reached their peaks). Thus during the bubble in the euro stock markets from 2003 to 2007, during which stock prices almost doubled (as rents also increased the ratio of prices to rents shown above increased much less), bank credit in the euro zone increased by $60 \%$ (from 95\% of euro area GDP to 115\%).

Thus during the period 2003-07 statistical evidence was available to detect threats to financial stability ${ }^{10}$. The period 2003-08 showed the classical combination of asset price booms fuelled by excessive bank credit, which ultimately leads to a crash and a financial crisis. (See also Borio (2003) on this issue with more empirical evidence of the importance of these twin variables to explain subsequent financial crisis). We conclude that it is possible for a central bank to monitor the risk of financial crisis by focusing on a limited number of indicators, i.e. on indices of stock prices and housing prices and on bank credit.

\footnotetext{
${ }^{9}$ The ECB's definition of financial stability is too vague to be useful in tying down its responsibilities. According to the ECB “...financial stability is a condition in which the financial system - comprising financial intermediaries, markets and market infrastructures - is capable of withstanding shocks and the unraveling of financial imbalances.” ECB (2008), p. 117.

${ }^{10}$ There were also observers at the BIS and in academia who, based on similar evidence, warned of imminent financial crises.
} 
Figure 3: Stock price indices in the euro area and in the US

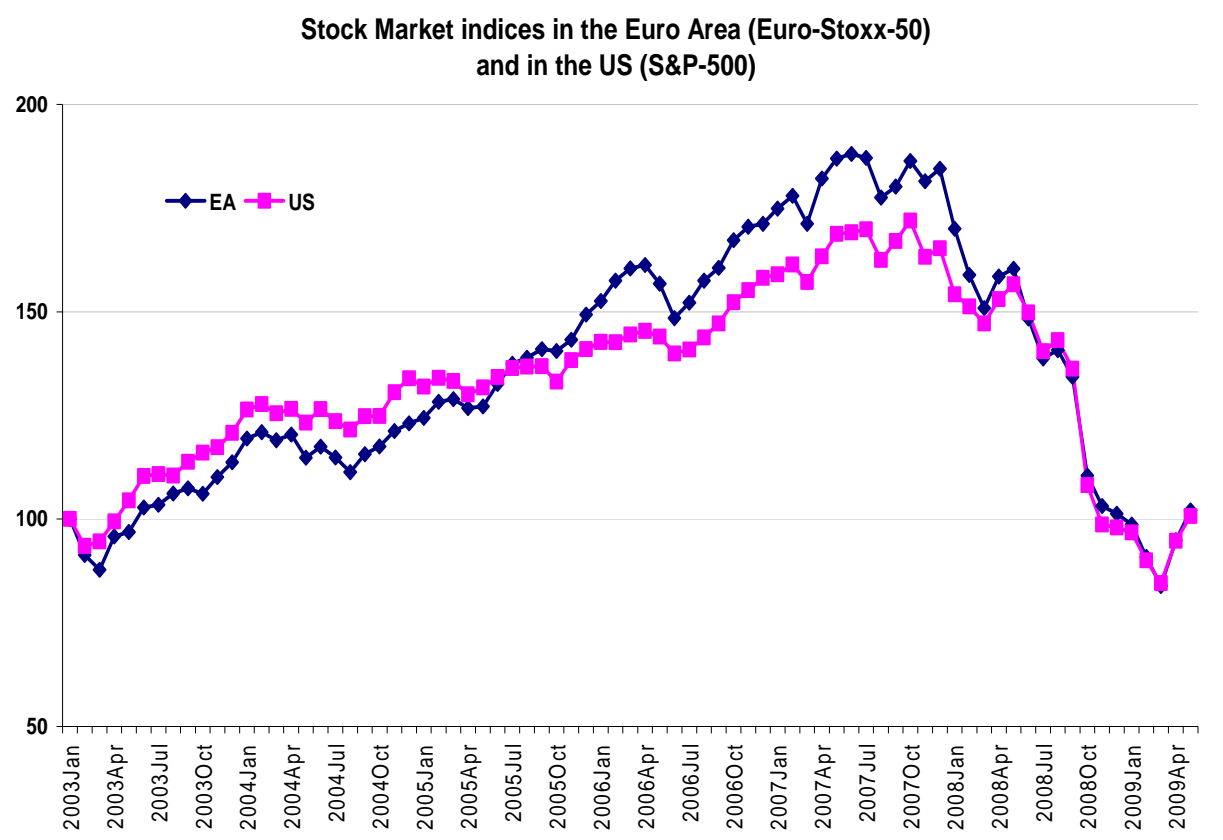

Source: European Central Bank, Statistical Data Base, various issues.

Figure 4: Growth rate of total bank loans (left) and stock price index (right) in the euro area

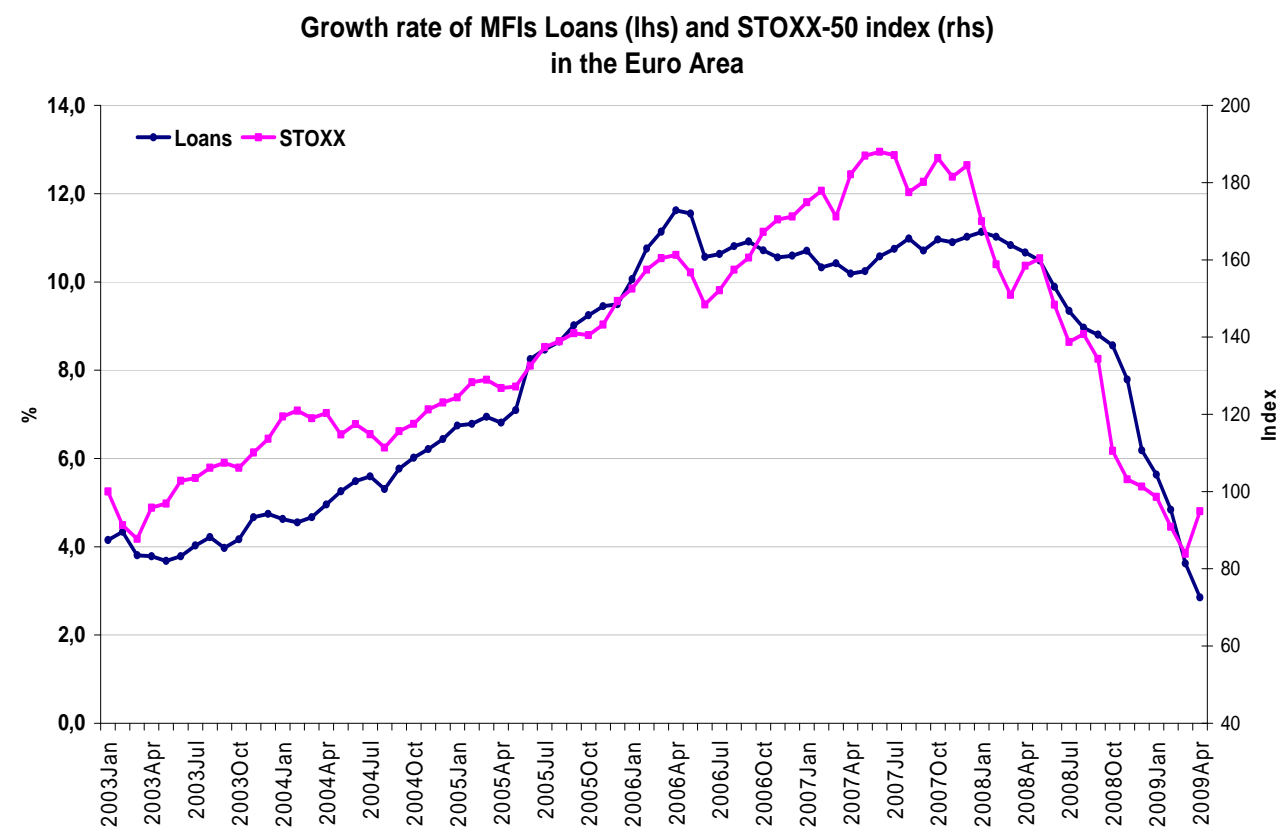

Source: European Central Bank, Statistical Data Base, various issues. 
One issue that arises here is why central bankers in Europe (the ECB, the Bank of England) and the US (the Federal Reserve) put so little weight on these indicators? There are probably many factors that have influenced the failure of central bankers to detect the threats to financial stability. There is one factor that we want to stress here. Central Bankers were "fed intellectually" by macroeconomic models developed in academia. These models were based on the assumption of perfectly informed and superbly rational agents who cannot make systematic errors, and who understand the great complexity of the world in which they live. In these "dynamic stochastic general equilibrium" models (DSGE models) that are now widely used in central banks, bubbles and crashes cannot occur. Prices always reflect underlying fundamentals. There is no need to do anything about asset prices.

These models tell the policy-makers to focus on price stability and all the rest - growth and stability - will be given to them by the efficient working of the markets ${ }^{11}$. Such an intellectual framework can easily work as an intellectual device that prevents policymakers from seeing emerging problems in the financial markets, because in the models these problems can simply not arise. And when they arise, they are just exogenous shocks that could not be seen in advance.

\section{Policy instruments for financial stability}

Giving the responsibility for financial stability to central banks is one thing, providing the instruments to achieve the objective of financial stability is something else. Clearly, with just one instrument, the interest rate, the central bank will have great difficulties to achieve price stability and financial stability, let alone output stability. In fact, adding an objective without giving the central bank additional instruments to achieve that objective is not very sensible. In addition, without additional instruments it is difficult to make the central bank accountable for the additional objective.

Fortunately, there are instruments at the disposal of the central bank that can be used to maintain financial stability. These instruments are (1) legal reserve requirements, and (2) macroprudential control. We discuss these consecutively:

\section{Legal reserve requirements}

The ECB has the formal legal authority to impose the minimum reserve holdings by banks in the euro zone. It has, however, not used this variable as an instrument of monetary policy, and has not changed the levels of minimum reserves since the start of its operations.

\footnotetext{
${ }^{11}$ For a strong formulation of this view see Stark (2008) in a speech of 18/11/2008: "The mandate of the ECB is to maintain price stability over the medium term. This mandate must be adhered to both in normal times and in times of crisis. The monetary policy stance appropriate to fulfill our mandate depends exclusively on our assessment of the balance of risks to price stability, and nothing else. [...] There is no trade-off between price stability and financial stability". For another skeptical note on the existence of a trade-off between financial stability and price stability, see Bini-Smaghi (2008).
} 
Required reserves work like a tax on bank deposits because it forces banks to hold funds equal to a certain percentage (at present 2\%) of their deposits with the central banks. In the euro zone reserve requirements are remunerated at close to market rates. This was done because it was feared that otherwise banking business would migrate outside the euro area. However, reserve requirements still work like a tax at the margin as can be seen from the fact that during normal times banks do not leave any excess reserves with the ECB.

There is no reason why the ECB could not use this instrument in the context of its objective of preserving financial stability. We propose that $2 \%$ would be the normal percentage to be used in normal times. During periods of excessive credit growth, like during the period 2003-07, the ECB could raise the minimum reserves to be held by banks to a higher level depending on the size of the credit growth. In so doing the ECB would increase the cost of extending bank credit and would discourage credit expansion in the banking system. Such an action would of course have been deeply unpopular with the banking system and might have led to some migration of deposits off shore. However, in light of recent events such a reaction might actually not have been contrary to the longer-term interests of the euro area.

If the ECB had increased reserve requirements (say from 2004 onwards) to reign in credit growth, deposits might have migrated to London. However, this would have actually made it easier to support the euro area banking system during the crisis as the fiscal cost of guaranteeing for all these deposits would have had to be borne by the UK authorities.

\section{Macro-prudential control}

Macro-prudential control refers to the use of prudential control of the banks with the aim of achieving a macroeconomic outcome conducive to financial stability. The two instruments most often cited in this context are loan to value ratios and leverage ratios.

Some form of macroprudential control has been applied by a number of national central banks (NCBs), most prominently by the Bank of Spain, which has implemented a system of countercyclical reserve accumulation which required banks to set aside more funds for bad debt than appeared to be needed during the boom (so called dynamic provisioning).

There is a consensus today that while this policy has not prevented a boom in the Spanish construction sector, it has mitigated the impact of the now ongoing bust in shielded the Spanish banking sector from taking excessive risks, thereby limiting the impact of the financial crisis on the sector.

The issue that arises here is whether such a macroprudential control mechanism could be transferred to the ECB. Our opinion is that it can be done without having to change the statutes of the ECB. In our view a macroprudential control exerted by the ECB should be restricted to the systemic banks that have activities throughout the euro zone ${ }^{12}$. The exact

\footnotetext{
12 Several members of the Governing Council have recently proposed to give the ECB more authority in supervising the systemic banks. See Financial Times (2009). The ECB position on financial stability in the past and during the current financial crisis can be found in several sources: ECB press releases and publications (see for example ECB (2008), Trichet (2008), but also Cecchetti and Schoenholtz (2008).
} 
numbers of the banks that would fall under this category could be determined on the basis of objective criteria (mainly the size of cross-border, especially interbank operations).

Transferring the authority for banking supervision to the ECB would not require a change in the Treaty. A (unanimous) decision of the Council would be sufficient under Article 105 of the Treaty (Maastricht Treaty). This might be difficult to achieve, but an alternative route exists: the ECB could simply decide that it would deal only with banks whose solidity it can control itself. The ECB could then set simple criteria (e.g. overall leverage and liquidity ratios) and invite banks that wish to participate in its tenders to open their books to the appropriate department in the ECB. This would de facto create a group of 'clearing banks', which would have the explicit stamp of approval of the ECB. All financially strong banks would have an incentive to be part of this group so there would be no need to force them to open their books to the ECB, which would then, de facto, become a sort of supervisor for them (because it could take away access to its facilities if the bank does not fulfil its criteria) ${ }^{13}$.

\section{A new two-pillar system}

The previous discussion allows us to propose a new two-pillar system for the ECB. This is a system in which the interest rate would continue to be used for achieving the inflation objective, while the other instruments (legal reserve requirements and macroprudential control) would be used to achieve financial stability. Thus we propose a separation of the two sets of instruments which is akin to what the ECB has been doing since the start of the liquidity crisis in the summer of 2007, when it used the interest rate to achieve its macroeconomic objectives and used quantitative liquidity provisions independently from the interest rate decisions. This allowed the Eurosystem to provide all the necessary liquidity independently from the interest rate.

A similar separation would be possible between the use of legal reserve requirements and macroprudential control on the one hand, and the use of the interest rate on the other hand. Such a separation would allow the ECB to reserve the interest rate as the privileged instrument to control inflation (which is the present situation) and the other instruments, legal reserve requirements and macroprudential controls, as the privileged instruments to maintain financial stability. The advantage of such a separation is that it would be easier for the ECB to handle the difficult trade-offs that can occur between financial stability and price stability.

Thus the ECB could have applied such a separation during the period 2003-07. This would have allowed it to set the interest rate as its privileged instrument to keep inflation within the target zone. At the same time, observing that bank credit was increasing in an unsustainable way and that this coincided with several bubbles in asset markets, the ECB could have increased the minimum reserve requirements, lowered the loan-to-value ratio, and imposed lower leverage ratios on systemic banks. There is little doubt that this would

\footnotetext{
${ }^{13}$ We are indebted to Tommaso Padoa Schioppa for pointing this idea out to one of us. We realize that it would require a decision of the ECB's Governing Council to implement this change. Unfortunately the national central bank presidents have a large majority on the Governing Council and they face a conflict of interest: this change might be in the interest of the ECB (and the euro zone), but might not be in the interest of 'their' banks, many of which might no longer qualify for access to the ECB's financing facilities.
} 
have reduced the expansion of bank credit during that period. Since a large part of the expansion of bank credit was channelled into asset markets (including housing markets) this would also have reduced the bubbles in these asset markets. The attractive feature of this separation of instruments is that the ECB could have achieved this without the need to raise the interest rate. This is an important advantage, because the use of the interest rate to counter asset bubbles encounters a lot of political opposition and criticism.

It will be remembered that in its initial monetary policy strategy, the ECB had set the growth rate of M3 as a reference value (intermediate target) for guiding the economy towards price stability. It is clear that this strategy has failed, as can be seen from Figure 5 . We observe that the growth rate of M3 by far exceeded the reference value of $4.5 \%$ which was the number the ECB announced to be the maximum that should not be exceeded if the inflation target of $2 \%$ is to be achieved. The facts are that the ECB came very close to achieving its inflation objective during 1999-2008 (it was $2.2 \%$ on average per year) while the growth rate of M3 wildly exceeded the $4.5 \%$ benchmark (it was $7.4 \%$ on average per year).

Figure 5: Inflation and money growth (M3) in the euro area

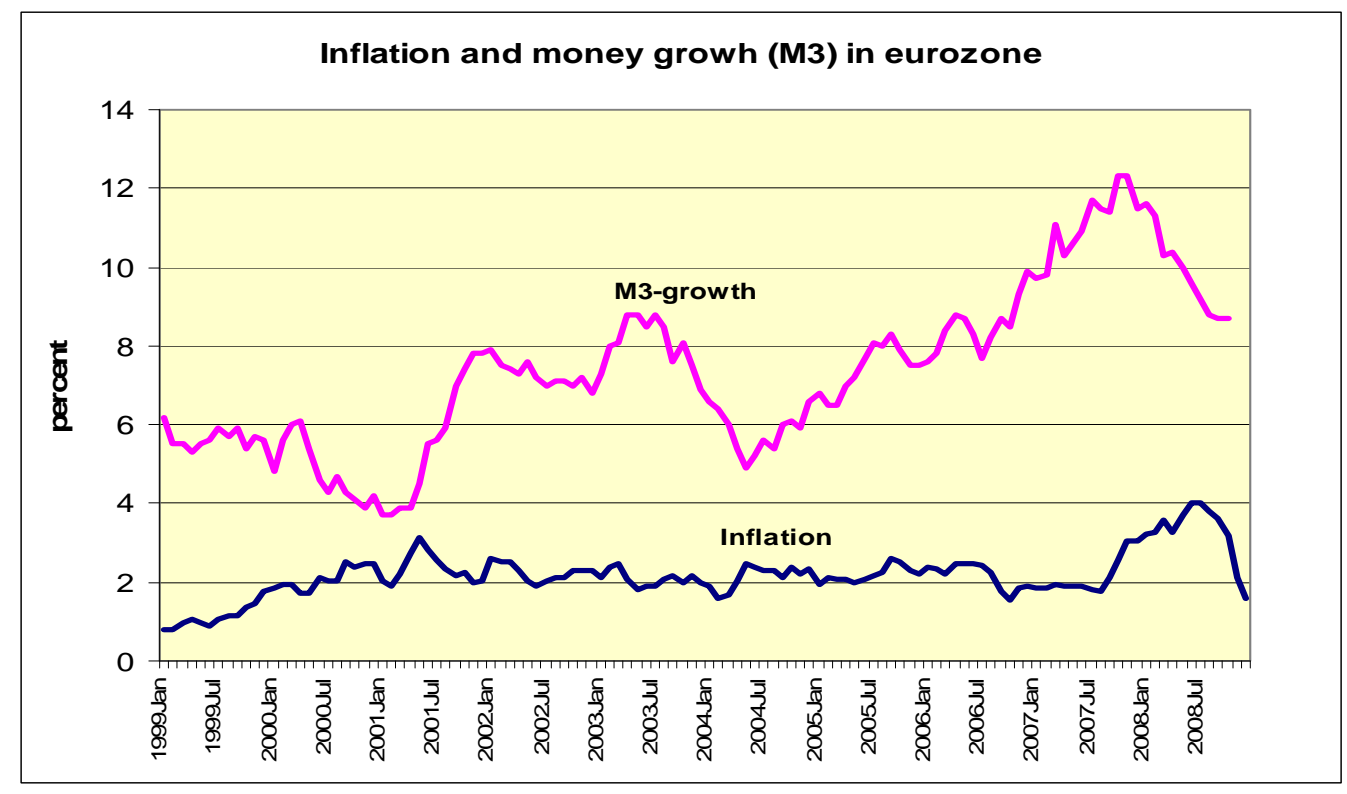

Source: ECB, Monthly Bulletin.

The failure to control the growth rate of monetary and credit aggregates, while inflation was very close to the objective of $2 \%$, is related to the phenomenon documented earlier, i.e. the excessive expansion of bank credit that was channelled mainly into asset markets, while leaving goods markets relatively unaffected. The two-pillar strategy proposed here would have allowed to solve this problem and to keep the growth rate of M3 (and of bank credit) under control while not driving the interest to very high levels.

Monetary and credit aggregates refer to two different sides of the balance sheet of banks, however, in reality they tend to move together. We illustrate this in two ways. Figure 6 
shows the growth rate of M3 and two credit aggregates relative to GDP because only strong increases in this ratio signal dangers to financial stability (if credit growth is in line with nominal GDP there is no increase in leverage and hence no danger to price stability). It is apparent that since 2003 the ratios of money and credit relative to GDP were increasing every rear, and at an increasing rate (until 2008).

Table 2 shows the correlation coefficients between the ratios of M3 to GDP and different ratios of loans to GDP. We observe that these correlations are very high, which again is not surprising as they are different sides of the banks' balance sheets.

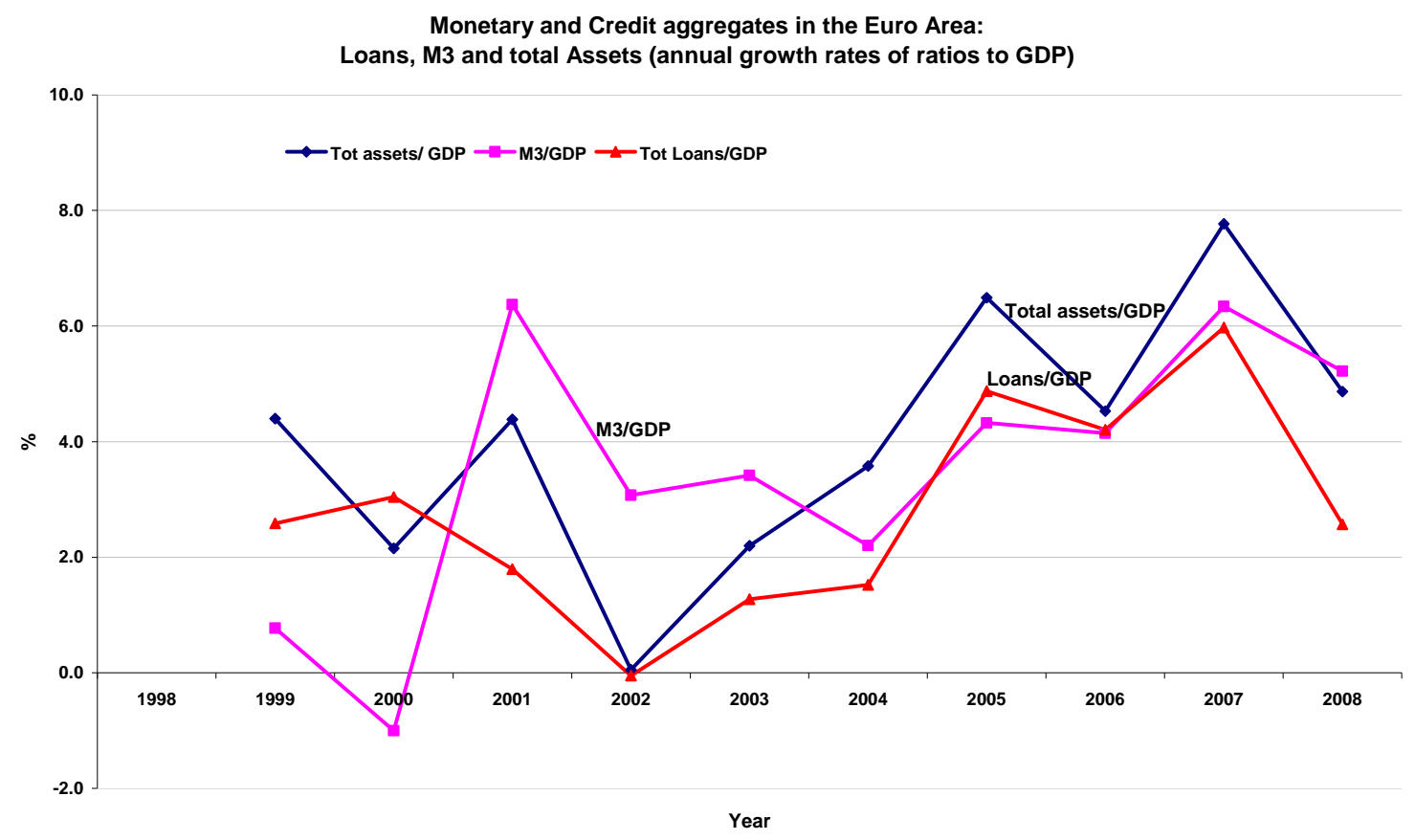

Table 2: Correlations between M3 and loans:

\begin{tabular}{|l|r|r|r|}
\hline & $\begin{array}{c}\text { Total assets/ } \\
\text { GDP }\end{array}$ & M3/GDP & Loans/GDP \\
\hline Tot assets/ GDP & 1 & & \\
\hline M3/GDP & 0.99 & 1.00 & \\
\hline Tot Loans/GDP & 1.00 & 0.98 & 1.00 \\
\hline
\end{tabular}

It is thus not surprising that in reality the ratios of credit aggregates to M3 (the credit/money multipliers) have been roughly constant. This suggests that the warning signs that one would have detected from looking at M3 would have been identical to those coming from broader credit aggregates. However, the ECB did not detect dangers for financial stability because of its exclusive focus on price stability.

We conclude that financial stability can become an explicit objective of the central bank. In addition, the central bank has a number of instruments that can be geared towards this 
objective. There remains, of course, the distribution of responsibilities between the supervisors and the central bank. We have argued that part of the supervisory responsibility (macroprudential control) can be transferred to the ECB. The ECB would then have powerful instruments (including legal reserve requirements) that would allow it to control the growth rate of bank credit. By narrowing down the ECB's responsibility to bank credit, the ECB could also be made accountable for excessive growth in bank credit.

Our proposal does not in any way diminish the need for strengthening the supervisory framework in the Eurozone. The ECB alone cannot guarantee financial stability. There is a need for a more effective supervision in the Eurozone. In order to achieve greater effectiveness of the supervisory framework some further centralisation of supervision will be necessary. The Larosière report (2009) provides a blueprint for such a stronger and more effective supervision in the Eurozone.

\section{Concluding remarks}

We have argued that financial stability should be an objective of the ECB which is at par with its "primary" objective of price stability and that at times there might be conflict between price and financial stability. We did not argue that this is always the case. However, booms and busts in financial markets have had a major influence on the global economy over the last decade. Preventing them must thus be a major task of public policy.

The experience of the 1970s and 1980s showed that maintaining price stability in the face of unfavourable external shocks required never-ending vigilance and the courage to take at times unpopular decisions. The experience of the 1990s and the first decade of this century should remind us that maintaining financial stability also requires constant vigilance and even more political courage since measures to stop bubbles are also deeply unpopular and have to be taken when the danger to financial stability is least apparent. Moreover, it is never straightforward to diagnose a bubble. A central bank that has among its objectives also explicitly financial stability might thus at times be wrong. It could thus be seen as stifling the developments of financial markets without a good reason.

However, if one wants to reduce the likelihood of future major financial busts in the euro area one should accept that the ECB cannot only be responsible for price stability. Maintaining financial stability by preventing excesses in financial markets should be an equally important objective.

While the objective of price stability can be quantified relatively easily this is much less the case with financial stability. Thus the pursuit of financial stability as an objective of the central bank involves more judgement. We argued though that the trends in two variables, asset prices and bank credit, usually provide a sound basis to detect dangers of financial instability.

It is important to stress here that conflicts between the two objectives of price stability and of financial stability can be resolved by making it possible for the ECB to use two instruments. This is the separation principle we propose. The ECB could continue to use 
the interest rate to achieve its inflation target while using reserve requirements and macroprudential controls to maintain financial stability.

There is little reason to fear that this change would lead to higher inflationary expectations (or in general to an un-anchoring of expectations). On the contrary, markets would then know that the ECB would have an instrument to prevent asset bubbles from getting out of hand, which should stabilize expectations.

Following the European Council meeting of June 2009 the EU has embarked on the creation of European Systemic Risk Council (ESCRC, as proposed originally in the de Larosière Report) whose main task will be to monitor systemic risk in the financial system of the EU. It is foreseen that the ECB will be closely involved in the running of the ESRC. However, this new institution will only be able to issue recommendations. It will in all likelihood not have any instruments to prevent dangers to financial stability. The establishment of the ESRC thus does not diminish in any way the need to update the mandate for the ECB by adding financial stability as a second key objective. 


\section{References}

Alessi L. and C. Detken, 2008, 'Real Time' Early Warning Indicators for Costly Asset Price Boom/Bust Cycles. A Role for Global Liquidity, ECB Working Paper Series 1039/March 2009.

Bernanke B. S. and M. Gertler (2000), Monetary Policy and Asset Price Volatility NBER Working Paper 7559

Bordo M. D. and O. Jeanne (2002), Monetary Policy and Asset Prices: Does the Benign Neglect Make Sense? IMF Working Paper 225.

Borio C. and P. Lowe, 2002, Asset Prices, Financial and Monetary Stability, BIS Working Paper, n. 114

Borio C., 2003, Towards a Macroprudential Framework for Financial Supervision and Regulation?, BIS Working Paper, n. 128

Borio C., 2005, The Search for the Elusive Twin Goals of Monetary and Financial Stability, National Institute Economic Review

Bullard J. B and E. Schaling (2002), Why the Fed Should Ignore the Stock Market Federal Reserve Bank of St. Louis Review, March 2002, pp. 35-42

Brunnermeier, M. A. Crocket, C. Goodhart, D. Persaud and H. Shin (2009) “The Fundamental Principles of Financial Regulation”, Geneva Reports on the World Economy 11

Debelle, G., 1997, Inflation Targeting in Practice, International Monetary Fund IMF Working Paper, n. 97/35

ECB, 2008, Financial Stability and Oversight, Monthly Bulletin - 10th Anniversary of the ECB

Ferguson R. W., 2002, Should Financial Stability Be an Explicit Central Bank Objective?, IMF Conference on Challenges to Central Banking from Globalized Financial Systems, September 16-17 2002, Washington DC

Financial Times, 2009, ECB seeks wider policing power, 05/01/2009

Greenspan, A., 2007, The Age of Turbulence. Adventures in a New World, Penguin Books, London, England, 531 pages

Issing, Otmar (2009) "In search of monetary stability: the evolution of monetary policy”, Bank for International Settlements, BIS Working Paper No. 273, Basle, March.

Kindleberger C., 2000, Manias, Panics, and Crashes, 5th Ed., New York: Wiley.

Larosière, de J., (2009), The High-Level Group on Financial Supervision in the EU, Brussels.

Roubini N. (2006), Why Central Banks Should Burst Bubbles International Finance Vol.1 No.1, pp.87-107 
Stark J., 2008, Monetary, Fiscal and Financial Stability in Europe, Speech by Jürgen Stark, Member of the Executive Board of the ECB, 11th Euro Finance Week in Frankfurt, 18 November 2008

(http://www.ecb.int/press/key/date/2008/html/sp081118_1.en.html)

Svensson Lars E. O., 2003, What Is Wrong with Taylor Rules? Using Judgment in Monetary Policy through Targeting Rules, Journal of Economic Literature, Vol. 41, n. 2, pp. 426-477

Walsh C. E., 1995, Recent Central Bank Reforms and the Role of Price Stability as the Sole Objective of Monetary Policy, NBER Macroeconomic Annual, Vol. 10, pp. 237-252

White W. R., 2006, Is Price Stability Enough? BIS Working Paper No. 205 


\section{CESifo Working Paper Series}

for full list see www.cesifo-group.org/wp

(address: Poschingerstr. 5, 81679 Munich, Germany, office@cesifo.de)

2757 Mirco Tonin and Michael Vlassopoulos, Disentangling the Sources of Pro-social Behavior in the Workplace: A Field Experiment, August 2009

2758 Nicole Grunewald and Inmaculada Martínez-Zarzoso, Driving Factors of Carbon Dioxide Emissions and the Impact from Kyoto Protocol, August 2009

2759 Yu-Fu Chen and Michael Funke, Booms, Recessions and Financial Turmoil: A Fresh Look at Investment Decisions under Cyclical Uncertainty, August 2009

2760 Jan-Egbert Sturm and Jakob de Haan, Does Central Bank Communication really Lead to better Forecasts of Policy Decisions? New Evidence Based on a Taylor Rule Model for the ECB, August 2009

2761 Larry Karp, Sacrifice, Discounting and Climate Policy: Five Questions, August 2009

2762 Marianna Belloc and Samuel Bowles, International Trade, Factor Mobility and the Persistence of Cultural-Institutional Diversity, August 2009

2763 Charles Noussair and Fangfang Tan, Voting on Punishment Systems within a Heterogeneous Group, August 2009

2764 Birgit Bednar-Friedl and Karl Farmer, Internationally Coordinated Emission Permit Policies: An Option for Withdrawers from the Kyoto Protocol?, August 2009

2765 Pierre M. Picard and David E. Wildasin, Labor Market Pooling, Outsourcing and Labor Contracts, August 2009

2766 Stefan Voigt and Lorenz Blume, The Economic Effects of Federalism and Decentralization - A Cross-Country Assessment, August 2009

2767 David S. Jacks, Christopher M. Meissner and Dennis Novy, Trade Booms, Trade Busts, and Trade Costs, August 2009

2768 Mario Jametti and Thomas von Ungern-Sternberg, Hurricane Insurance in Florida, August 2009

2769 Alessandro Balestrino, Kind of Black: The Musicians' Labour Market in Italy, August 2009

2770 Yosr Abid Fourati and Cathal O’Donoghue, Eliciting Individual Preferences for Pension Reform, August 2009

2771 Christian Breuer and Chang Woon Nam, VAT on Intra-Community Trade and Bilateral Micro Revenue Clearing in the EU, August 2009 
2772 Choudhry Tanveer Shehzad, Jakob De Haan and Bert Scholtens, Growth and Earnings Persistence in Banking Firms: A Dynamic Panel Investigation, August 2009

2773 Erdal Yalcin, Uncertain Productivity Growth and the Choice between FDI and Export, August 2009

2774 Klaus Abberger, Wolfgang Nierhaus and Shynar Shaikh, Findings of the Signal Approach for Financial Monitoring in Kazakhstan, September 2009

2775 Sascha O. Becker, Francesco Cinnirella and Ludger Woessmann, The Trade-off between Fertility and Education: Evidence from before the Demographic Transition, September 2009

2776 Thomas Aronsson and Erkki Koskela, Optimal Income Taxation, Outsourcing and Policy Cooperation in a Dynamic Economy, September 2009

2777 Joel Slemrod, Old George Orwell Got it Backward: Some Thoughts on Behavioral Tax Economics, September 2009

2778 Cagri Seda Kumru and Athanasios C. Thanopoulos, Social Security Reform and Temptation, September 2009

2779 Alessandro Bucciol and Roel M. W. J. Beetsma, Inter- and Intra-generational Consequences of Pension Buffer Policy under Demographic, Financial and Economic Shocks, September 2009

2780 Eduardo Strube and Marcelo Resende, Complementarity of Innovation Policies in the Brazilian Industry: An Econometric Study, September 2009

2781 Henry Tulkens and Vincent van Steenberghe, "Mitigation, Adaptation, Suffering": In Search of the Right Mix in the Face of Climate Change, September 2009

2782 Maria L. Loureiro, Anna Sanz-de-Galdeano and Daniela Vuri, Smoking Habits: Like Father, Like Son, Like Mother, Like Daughter, September 2009

2783 Momi Dahan, Tehila Kogut and Moshe Shalem, Do Economic Policymakers Practice what they Preach? The Case of Pension Decisions, September 2009

2784 Eytan Sheshinski, Uncertain Longevity and Investment in Education, September 2009

2785 Nannette Lindenberg and Frank Westermann, How Strong is the Case for Dollarization in Costa Rica? A Note on the Business Cycle Comovements with the United States, September 2009

2786 Leif Danziger, Noncompliance and the Effects of the Minimum Wage on Hours and Welfare in Competitive Labor Markets, September 2009

2787 Gerlinde Fellner, Rupert Sausgruber and Christian Traxler, Testing Enforcement Strategies in the Field: Legal Threat, Moral Appeal and Social Information, September 2009 
2788 Gabriel J. Felbermayr, Mario Larch and Wolfgang Lechthaler, Unemployment in an Interdependent World, September 2009

2789 Sebastian G. Kessing, Federalism and Accountability with Distorted Election Choices, September 2009

2790 Daniel Gros, Global Welfare Implications of Carbon Border Taxes, September 2009

2791 Louis N. Christofides, Michael Hoy and Ling Yang, The Gender Imbalance in Participation in Canadian Universities (1977-2005), September 2009

2792 Jan K. Brueckner and Robert W. Helsley, Sprawl and Blight, September 2009

2793 Vidar Christiansen and Stephen Smith, Externality-correcting Taxes and Regulation, September 2009

2794 John Beirne, Guglielmo Maria Caporale, Marianne Schulze-Ghattas and Nicola Spagnolo, Global and Regional Spillovers in Emerging Stock Markets: A Multivariate GARCH-in-mean Analysis, September 2009

2795 Rüdiger Pethig and Frieder Kolleß, Asymmetric Capital-Tax Competition, Unemployment and Losses from Capital Market Integration, September 2009

2796 Ngo Van Long, Horst Raff and Frank Stähler, Innovation and Trade with Heterogeneous Firms, September 2009

2797 Margit Osterloh and Bruno S. Frey, Research Governance in Academia: Are there Alternatives to Academic Rankings?, September 2009

2798 Thiess Buettner and Clemens Fuest, The Role of the Corporate Income Tax as an Automatic Stabilizer, September 2009

2799 Annette Alstadsæter, Measuring the Consumption Value of Higher Education, September 2009

2800 Peter Friedrich, Chang Woon Nam and Janno Reiljan, Local Fiscal Equalization in Estonia: Is a Reform Necessary?, September 2009

2801 Evžen Kočenda and Jan Hanousek, State Ownership and Control in the Czech Republic, September 2009

2802 Michael Stimmelmayr, Wage Inequality in Germany: Disentangling Demand and Supply Effects, September 2009

2803 Biswa N. Bhattacharyay, Towards a Macroprudential Surveillance and Remedial Policy Formulation System for Monitoring Financial Crisis, September 2009

2804 Margarita Katsimi, Sarantis Kalyvitis and Thomas Moutos, "Unwarranted" Wage Changes and the Return on Capital, September 2009 
2805 Christian Lessmann and Gunther Markwardt, Aid, Growth and Devolution, September 2009

2806 Bas Jacobs and Dirk Schindler, On the Desirability of Taxing Capital Income to Reduce Moral Hazard in Social Insurance, September 2009

2807 Hans Gersbach and Noemi Hummel, Climate Policy and Development, September 2009

2808 David E. Wildasin, Fiscal Competition for Imperfectly-Mobile Labor and Capital: A Comparative Dynamic Analysis, September 2009

2809 Johan Eyckmans and Cathrine Hagem, The European Union's Potential for Strategic Emissions Trading through Minimal Permit Sale Contracts, September 2009

2810 Ruediger Bachmann and Christian Bayer, The Cross-section of Firms over the Business Cycle: New Facts and a DSGE Exploration, October 2009

2811 Slobodan Djajić and Michael S. Michael, Temporary Migration Policies and Welfare of the Host and Source Countries: A Game-Theoretic Approach, October 2009

2812 Devis Geron, Social Security Incidence under Uncertainty Assessing Italian Reforms, October 2009

2813 Max-Stephan Schulze and Nikolaus Wolf, Economic Nationalism and Economic Integration: The Austro-Hungarian Empire in the Late Nineteenth Century, October 2009

2814 Emilia Simeonova, Out of Sight, Out of Mind? The Impact of Natural Disasters on Pregnancy Outcomes, October 2009

2815 Dan Kovenock and Brian Roberson, Non-Partisan 'Get-Out-the-Vote' Efforts and Policy Outcomes, October 2009

2816 Sascha O. Becker, Erik Hornung and Ludger Woessmann, Catch Me If You Can: Education and Catch-up in the Industrial Revolution, October 2009

2817 Horst Raff and Nicolas Schmitt, Imports, Pass-Through, and the Structure of Retail Markets, October 2009

2818 Paul De Grauwe and Daniel Gros, A New Two-Pillar Strategy for the ECB, October 2009 